\title{
HISTOCHEMICAL STUDIES OF RHEUMATIC CONDITIONS \\ II. THE NODULE OF RHEUMATOID ARTHRITIS
}

BY

\author{
H. T. FAWNS AND J. W. LANDELLS \\ From the Department of Pathology, Royal Infirmary, Worcester, \\ and the Bernhard Baron Institute of Pathology, London Hospital
}

(RECEIVED FOR PUBLICATION JANUARY 20, 1954)

Previous work on the present lines has been carried out by Glynn and Loewi (1952) on the nodule associated with rheumatic carditis. It is desirable to emphasize that the nodules of rheumatoid arthritis, although similar, are not the same, and that the actual enzyme preparations used were different; so that any differences between the results reported by these workers and those reported here do not necessarily imply a conflict between their findings and ours. Further, our findings are not necessarily applicable to fibrinoid changes described in many situations in other diseases.

\section{Material and Methods}

The nodules were excised under local anaesthesia and sectioned either immediately or after a few days' storage in a container at $-40 \mathrm{C}$. Part of the nodule was fixed in 70 per cent. ethanol and cut after paraffin embedding; the remainder was cut on the freezing microtome without fixation to avoid artefacts of fixation. Unstained sections were examined by phase-contrast and polarized light, with repeated photographs to follow the progress of digestion. The staining methods employed were:

(1) Iron haematoxylin and Van Gieson's stain for collagen.

(2) Periodic acid-Schiff (P.A.S.) for mucopolysaccharide (Hotchkiss, 1948); control sections were acted on with diastase and lipoid solvents to exclude false positive results from glycogen and lipoids.

(3) Laidlaw's silver impregnation for reticulin to show argyrophilia.

(4) Mallory's phosphotungstic acid-haematoxylin (P.T.A.H.) which stains collagen a reddishbrown and fibrin and fibrin-like substances a dark blue.

The enzyme preparations used were those described in our previous paper (Fawns and Landells, 1953), with the addition of a standard commercial preparation of pepsin (Light). Because of the expense of the collagenase and the frailty of the sections, incubation was usually carried out on slides under coverslips with a paraffin-vaseline seal. The duration and concentrations employed were:
Collagenase, trypsin, pepsin-1 mg. $/ \mathrm{ml}$. at $37^{\circ} \mathrm{C}$., $\frac{1}{2}$ to $20 \mathrm{hrs}$.

Hyalase (Benger) -1 ampoule $/ \mathrm{ml}$. at $37^{\circ} \mathrm{C}$., 2 to 48 hrs.

The specificity of the enzymes has been reported in our previous paper, but the efficiency and specificity of collagenase have since been called into question by Pearse (1953), though he gives no details of the experiments. It is true that its action is slow, and for dense material like adult human tendon exceedingly slow, but dermal collagen, taken as a control for these experiments from the knee or elbow, and the collagen of decalcified bone are reliably dissolved in some 15-30 hours, using a pure concentrated preparation. A suspension of rat-tail collagen $(10 \mathrm{ml}$.$) , made by the method of Nageotte and$ Guyon (1931), and incubated at 37 C. with $5 \mathrm{ml}$. of our collagenase solution, was completely digested to a waterclear solution in about 1 hour and 50 minutes, whereas control suspensions incubated with trypsin were unchanged after overnight incubation. Elastic fibres, keratin, fibrin, and all the other proteins tried, except gelatin, were untouched by collagenase. It will not act after formalin fixation, though it will act after alcohol fixation, but at a slower rate. No hyaluronidase activity was observed with the samples of collagenase used.

\section{Structure of the Nodule}

Although the studies of Collins (1937, 1939, 1949) make it unnecessary to go into great detail, it is desirable to outline the topography of the nodule so that no doubt remains as to the meaning of the descriptive terms used. As seen clinically, nodules mostly measure from 5 to $40 \mathrm{~mm}$. across, and are rounded, painless, and mobile. The cut surface of the smaller nodules shows a soft, yellow, central core, surrounded by a firm, hyaline, fibrous zone which merges indefinitely with the looser normal collagen of the dermis around. The larger nodules are formed by an agglomeration of similar areas.

Histological sections (Fig. 1, opposite)show this softened central core as an area of structureless material giving the staining reactions of fibrin, amongst which some bundles of collagen can usually be identified; there are no living cells in this area, though there may be nuclear debris, features which have given rise to the rather loose term "fibrinoid necrosis of collagen". Outside this, 


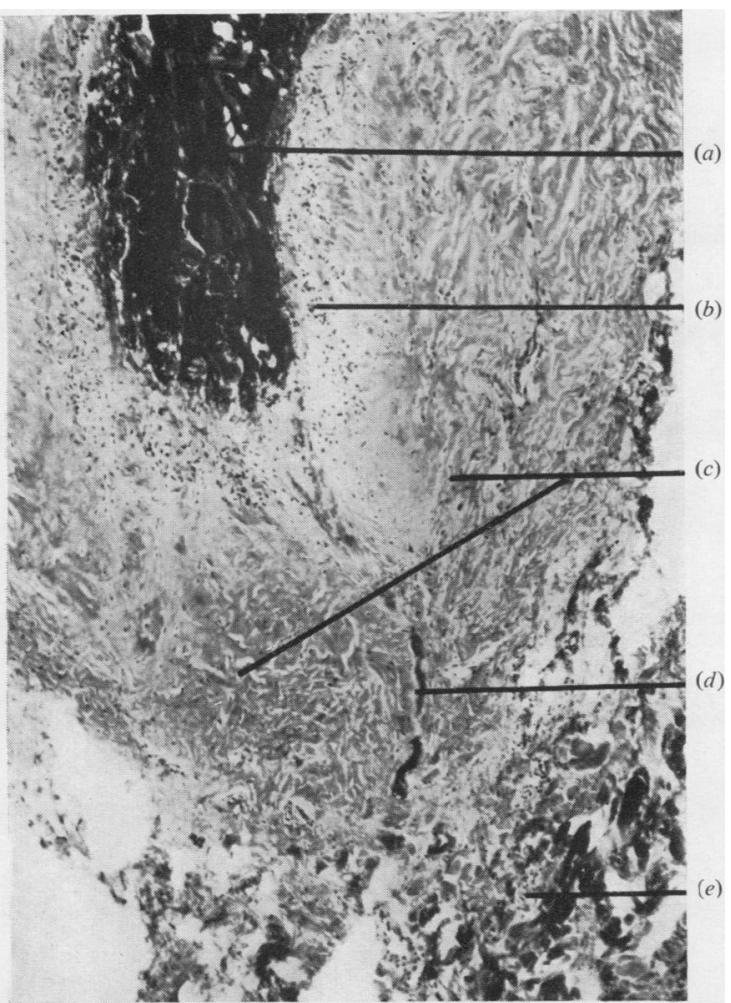

Fig. 1.-Zones of rheumatoid nodule. Paraffin section; phosphotungstic acid-haematoxylin; $\times 64$.

(a) fibrinoid core with faint collagen strands;

(b) corona cells;

(c) compact zone, paler and with different architecture;

(d) one strand dermal collagen passing along axis of nodule through compact zone to break up in fibrinoid zone;

(e) dermal collagen in darker looser bundles. there may be found a cellular zone, with large and sometimes multinucleate cells resembling fibroblasts or histiocytes arranged as a palisade around the core; among these are radially arranged collagen and reticulin fibres. Collins' term "corona" is a convenient brief title for these cells. They lie between the fibrinoid centre, and the encircling zone of compact fibrous tissue; some of them are found among the fibres of this zone. The periphery of the nodule merges with the loose original collagen of the dermis. The P.T.A.H. stain used for the photograph shows these points clearly and emphasizes the difference between the collagen of the compact zone and of the dermis. There are variations in detail in individual nodules and around the circumference of any single necrotic focus, which we believe to be due to the age changes going on in nodules in the living body.

\section{Results}

In the fresh section, the soft centre of the nodule can be seen to consist of two distinct elements: one fibrillar, the other granular (Fig. 2). In fixed sections, the granular material may appear either fibrillar or plastered up on the surface of the collagen fibres, and it is often difficult to distinguish the two elements. Bulk chemical analyses of fibrinoid will inevitably fail to separate the two elements and may include some of the surrounding collagen. There appears to be a place, therefore, for histochemical techniques with selective removal of the two components by specific enzymes followed by appropriate staining. The two elements can be separated; the enzyme collagenase dissolves the fibrillar material but not the granular, and trypsin dissolves the granular but not the fibrillar. The fibrillar material is traceable into the bundles of
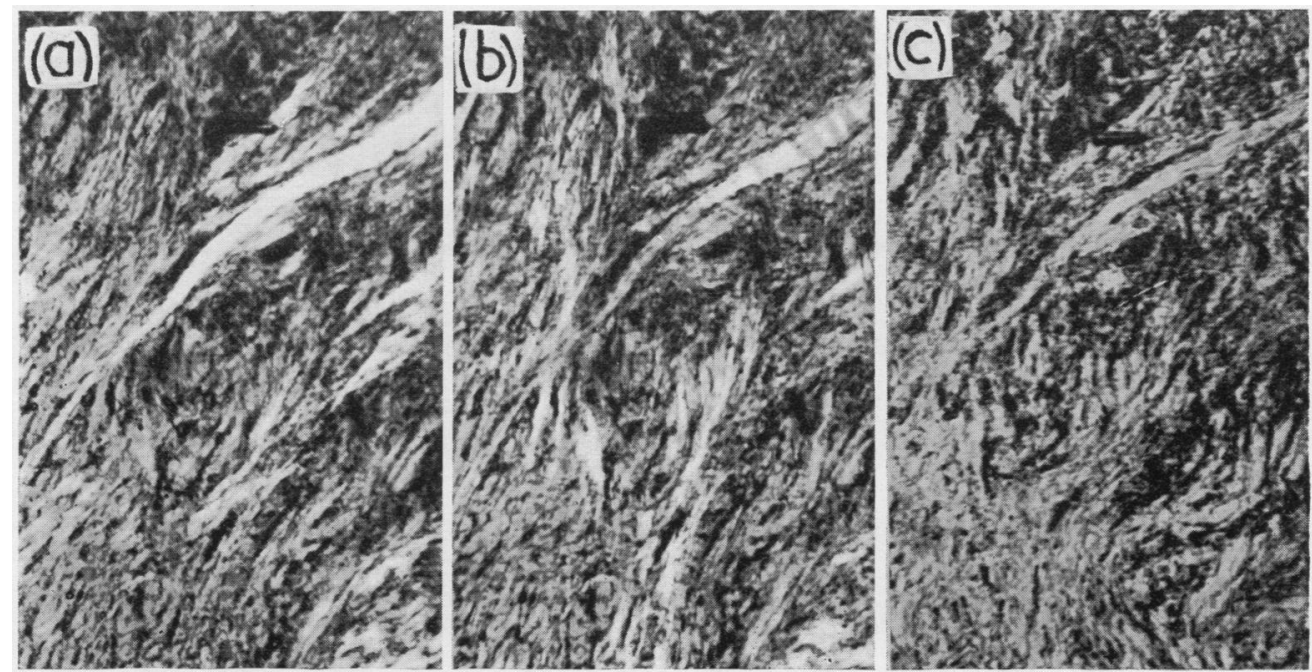

Fig. 2.-Action of collagenase. Fresh frozen sections; unstained; photographed first by ordinary light, then by polarized light on same negative, which shows up collagen as bright fibres; $\times 125$. (a) before digestion, (b) after 2 hrs, (c) after 4 hrs. 


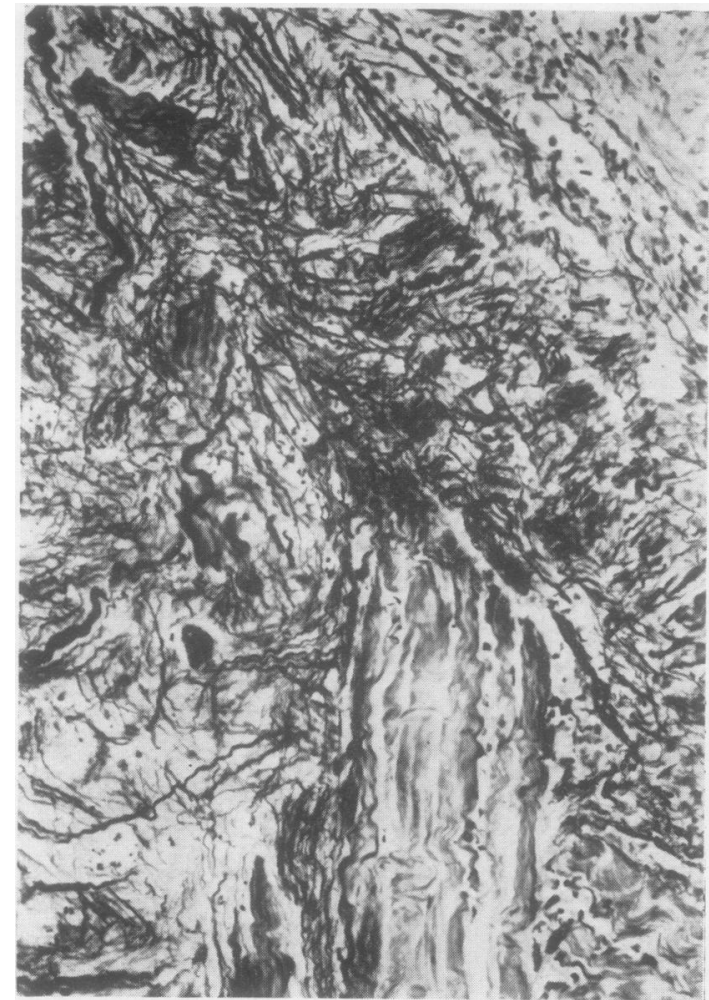

Fig. 3.-Argyrophilia and formation of nodule. Paraffin section; Laidlaw's reticulin stain; $\times 150$.

Early argyrophil change without much fibrinoid. Some collagen fibres of large bundle are grey (normal), others, on surface, are black (A-collagen); some finer fibres on right are probably new reticulin fibres in corona.

surrounding collagen, which it resembles in birefringence, but from which it differs in being argyrophil; it is not P.A.S. positive. The granular material has no normal counterpart, and is refractile but not birefringent; it is not argyrophil, but is strongly though variably P.A.S. positive.

Further consideration of the process of fibrinoid necrosis involves taking these components separately, and allowing for the secondary changes that take place in both materials in the history of the nodule. For brevity and simplicity, the granular material will be termed fibrinoid, and the argyrophil collagen will be termed $A$-collagen. The expression "fibrinoid necrosis" covers both the change of collagen into A-collagen and the accumulation around it of the fibrinoid.

(1) A-Collagen.-This material retains the enzyme susceptibility of the original collagen, i.e. it is dissolved by collagenase but not by trypsin. It is neither more nor less sensitive than normal collagen bundles of a similar size. It is not P.A.S.- or

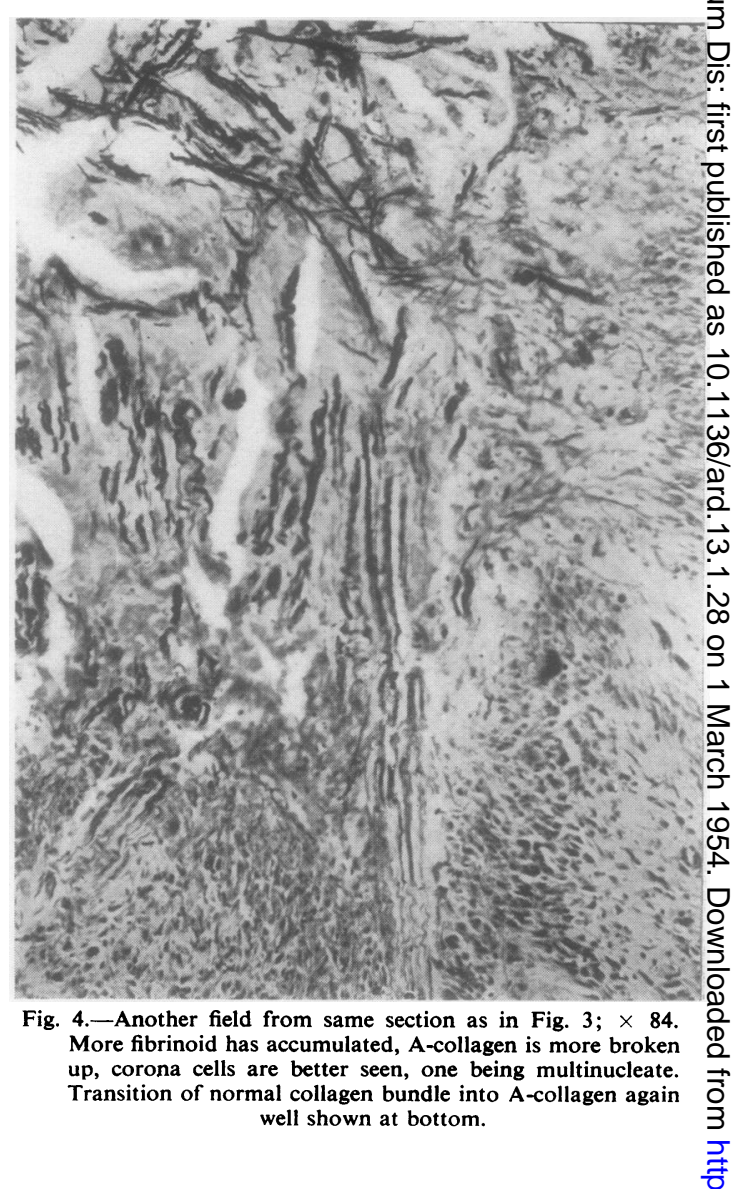

P.T.A.H.-positive as is the fibrinoid material. The important distinction between A-collagen and normal collagen appears to be the argyrophiliàshown by the former. At no stage in the digestion? of normal collagen by collagenase does argyrophiliab develop, nor have we obtained it by the action of other enzymes on collagen. It is safer at presento not to assume the identity of A-collagen and reticulin, especially as this is P.A.S.-positive: one iso connected with collagen in formation, the other with collagen in the process of destruction.

The expression "argyrophilia", applied to collagen or reticulin, is a simple term for a complex histo N logical reaction. It implies that the fibres will accept, after an essential preliminary series of washingso known as the Mallory bleach,* an incrustation of ammoniacal silver which can be reduced in situ to $\stackrel{+\infty}{+}$ metallic silver by substances such as formaldehyde. 0 Argyrophilia appears (Figs 3 and 4) to be asso

* Mallory bleach: 5 minutes each in Lugol's iodine, sodium? thiosulphate 5 per cent., potassium permanganate 0.25 per cent. oxalic acid 5 per cent., with intermediate washings. 
ciated with the break-up of larger bundles, which are non-argyrophil, except sometimes on the surface, but which are continuous with individual argyrophil fibres. These are at first elongated and sinuous (with sharper and wider curves than normal) but remain fibrillar. Eventually this material breaks up into smaller fragments and disappears, but the argyrophil change precedes this solution, and it is therefore unlikely that the argyrophilia relates to the aminoacid protofibril chain, since if this were deranged it would presumably result in the loss of fibrillar structure. It is therefore likely to be concerned either with the ground substance or with the sidechains.

(2) Fibrinoid.- This is present in fresh material as granular droplets of varying size, refractile but not birefringent. It is not argyrophil as above defined. It always stains orange to yellow with Van Gieson's stain, and is strongly P.A.S.-positive. In many, but not all areas, it stains dark bluish-black with

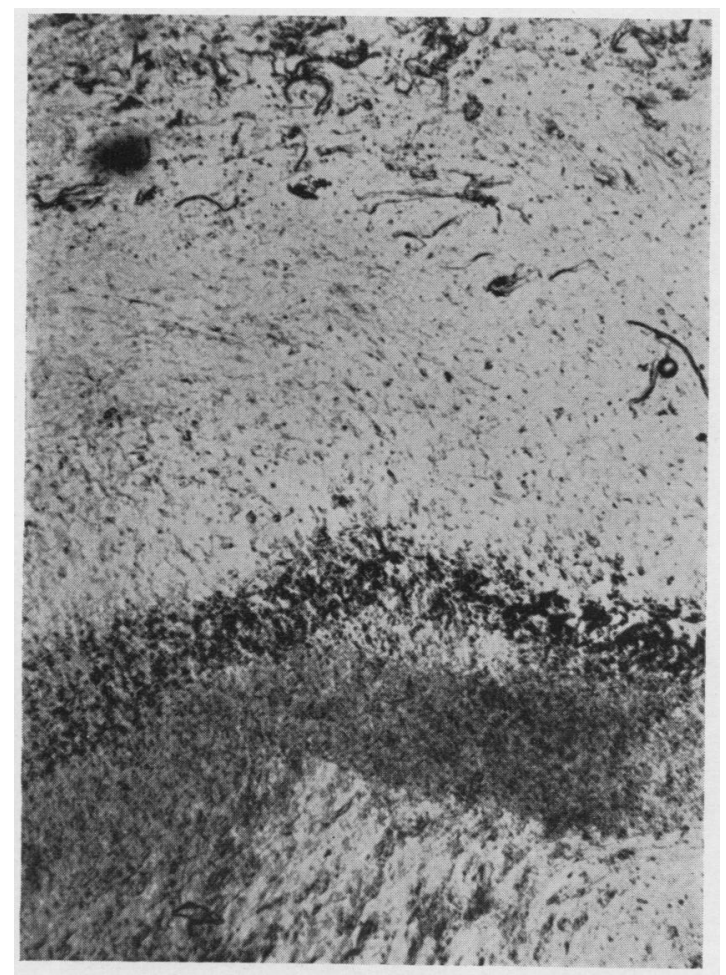

Fig. 5.-Action of collagenase, and two sizes of fibrinoid granules. Technique as in Fig. 2; fresh unstained frozen sections; $\times 95$. Collagenase action for $20 \mathrm{hrs}$. Bright collagen fibres absent, but elastic fibres of the subcutis undigested; elastic fibres almost absent from compact zone and fibrinoid. Two sizes of fibrinoid granule, with a sharp straight border above the large granular material, in position of corona cells.
P.T.A.H.; with ordinary haematoxylin and eosin it is bright red. These staining reactions, resembling those of fibrin, are responsible for the name. But recent biophysical studies by Kellgren and others (1951), and chemical analysis by Consden and others (1952), both strongly indicate that there is no fibrin, at any rate not in amounts sufficient to account for the bulk of material present.

The results of enzyme action on fibrinoid are quite different from the results on collagen. Fibrinoid is rapidly dissolved by trypsin, but is in any case appreciably soluble in water before fixation. It is not digested by hyalase, although the strong P.A.S. reaction suggests the presence of polysaccharide, nor is it metachromatic, differing in both points from the mucopolysaccharide of the normal ground substance of connective tissue. There are three possibilities which are not mutually exclusive:

(i) the chemical structure of this polysaccharide is not that of normal ground substance,

(ii) the polysaccharide is combined with protein in such a way that the reactive groups are blocked,

(iii) it may be attacked, but the cleavage products remain attached to protein and do not diffuse away.

The fibrinoid granules appear to be of two sizes, visible in the fresh section, but particularly conspicuous where the collagen has been removed by collagenase (Fig. 5). The smaller granules stain less strongly with P.A.S. and P.T.A.H., and are readily digested by both trypsin and pepsin; the larger, strongly P.A.S.- and P.T.A.H.-positive, are slowly digested by trypsin and withstand digestion by pepsin at a time when both collagen and the small granules have been completely removed (Figs 6 and 7, overleaf). This large granular material tends to lie near the corona cells.

\section{Discussion}

(1) Changes in Collagen.-Our observations suggest that the alteration of collagen takes place in the side-chains, since the A-collagen is still fibrillar, and argyrophilia cannot be demonstrated until the surface has been treated with agents, like the Mallory bleach or periodic-acid, which can be thought of as acting on the ground substance. Preliminary tests with blocking techniques suggest that the basic amino-acids, arginine and histidine, are concerned; this is in keeping with the chemical facts that they have the necessary groups to combine with acidic ground-substances. Their structure admits the possibility of the acceptance of silver, and argyrophilia has already been linked to histidine 

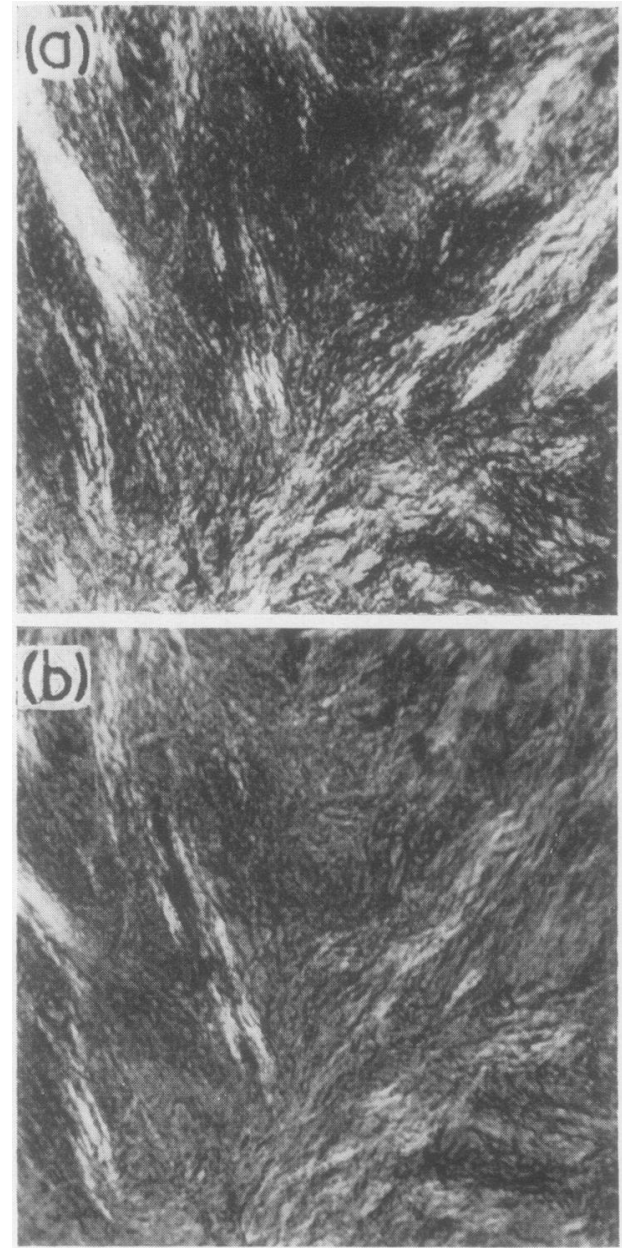

Fig. 6.-Action of hyalase and trypsin. Technique as in Fig. 2; fresh unstained frozen sections; $\times 125$.

(a) before and after hyalase-appearance unchanged acting as a control for $(b)$ consecutive section digested for $4 \mathrm{hrs}$ with trypsin. Dark fibrinoid material removed.

by the observations of Peters (1953). At the moment this is as far as our results will take us.

(2) Changes in Fibrinoid.-Only two histochemical reactions of this substance can be said to be firmly established: the strong P.A.S. reaction, indicating polysaccharide, under the conditions in which we have carried it out, and a strong reaction for tyrosine, demonstrated histochemically by Millon's reagent and chemically by Consden and others (1952). These are not observed with normal connective tissue; the quantity in which fibrinoid is found and these chemical differences make it improbable that fibrinoid results from a pathological change in the pre-existing material without the incorporation of adventitious material, which, for
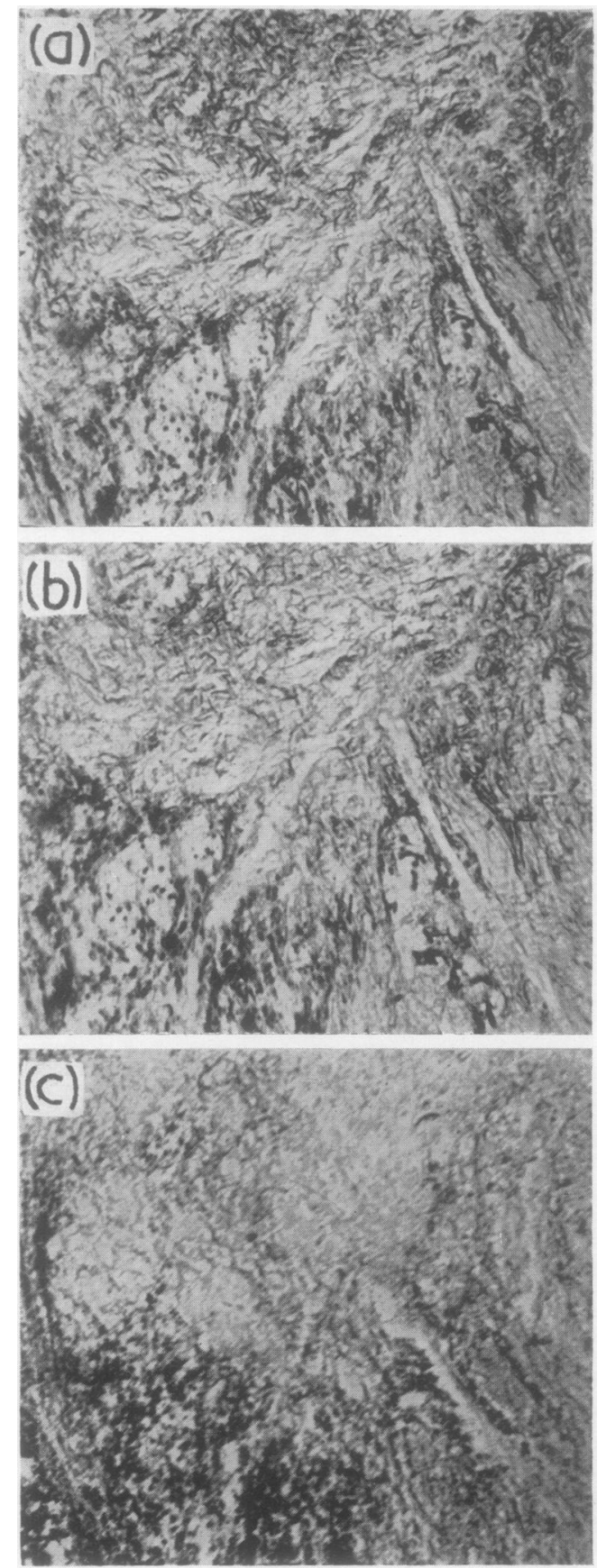

Fig. 7.-Action of pepsin. Technique as in Fig. 2; fresh unstained frozen sections; $\times 125$.

(a) before incubation,
(b) after 2 hrs,

(c) after 4 hrs.

Large granular material still present; collagen and small granules removed. 
the reasons given, is probably not fibrin. A substance new in components and considerable in quantity is more likely to represent a synthesis resulting from cellular activity than a passive degradation or accumulation of material. This synthesis could take place elsewhere in the body, and the product be deposited in the nodule, but it would be reasonable to credit the deposition to the local corona cells which often contain droplets of P.A.S.-positive material.

The coarsely granular, P.T.A.H.-positive fibrinoid is found in two places:

(i) as a sharply limited deposit in close relation to, but always internal to, the corona cells,

(ii) as an infiltrating deposit among fibres in parts of the nodule where the corona is lacking.

This second location must imply either that the rheumatoid degenerative process travels along the fibres, with fibrinoid being liberated from the fibres without the action of any cells (which is not very probable), or that the material is mechanically displaced (which is very likely to happen with a semifluid substance in the living body, with every movement). The fact that fibrinoid is sometimes found away from the corona is therefore not an insuperable objective to a suggestion that it is formed by the corona cells.

It would appear that the coarsely granular fibrinoid is the original form, and that the smaller granules (which are P.T.A.H.-negative, though still P.A.S.-positive) represent the first step in its degeneration. Later it becomes thinner and vacuolated, and occasionally other steps in its digestion are suggested by the metachromasia and basophilia which is seen regularly where phagocytes are present. The histological changes are much more easily explained by this sequence than by the reverse, or than by the supposition that a number of different sorts of fibrinoid are formed.

(3) Pathogenesis of the Nodule. - In the nodule shown in Fig. 1 the formation of zones is clearly seen around the dark bundle of fibres, and is traceable into the loosely-meshed collagen of the subcutis, like which it stains. This bundle passes right through the paler but more densely packed collagen of the compact zone and into the central area of fibrinoid necrosis, where it becomes broken up and argyrophil. It is hard to believe that this bundle, which is clearly formed of original collagen, and which lies in the axis of symmetry of the nodule, could be unrelated to the cause of the nodule, having merely been incorporated by chance into a degenerative process starting in some unexplained mass of new collagen. From the examination of many areas, it would appear that the order of events is as follows: firstly, the argyrophil change, then the arrival of corona cells, and then the formation of the fibrinoid and the surrounding compact zone in roughly corresponding quantities (Figs 3 and 4). Subsequent changes lead to the breakdown and absorption (often incomplete) of the fibrinoid. The corona cells which form a physical barrier to the displacement of the fibrinoid, may be concerned in its formation or solution, but the presence among them of reticulin and collagen fibres makes it reasonable to credit them with the formation of the compact zone; their position inside it would be hard to reach if they had not themselves laid it down from the inside.

These observations suggest that the rheumatoid process consists partly in a change in the collagen and partly in the failure of an active process of repair. When, as happens here, the process results in the formation of a mass of new tissue, it would appear more reasonable to think of it thus than as the primary degeneration in a static material, which is implied in the term "fibrinoid necrosis". The chemical site of this failure is still not clear, but the point to which our tentative observations direct attention is the facet where argyrophilia, collagenase action, and polysaccharide attachment appear to meet, namely, that relatively small part of the collagen amino-acid chain made up of the aminoacids arginine and histidine.

\section{Summary}

(1) The central soft area in the rheumatoid nodule consists of two elements:

(a) collagen fibres that have undergone a change which begins by rendering them argyrophil and ends in their destruction;

(b) a granular substance (fibrinoid) that is always strongly P.A.S.-positive and may show other staining reactions similar to those of fibrin.

(2) These two components are separable by enzyme action: collagen is removed by collagenase and the granular material by trypsin. This granular material appears in two forms: large granules resistant to pepsin, and small granules digested by pepsin. The larger granules are P.T.A.H.-positive and are probably the first to appear.

(3) Secondary changes in the course of the evolution of the nodule account for variations in its composition and therefore in its staining reactions.

(4) Active cellular synthetic processes as well as degenerative and necrotizing processes are necessary for the formation of the nodule.

We should like to thank Miss R. M. Jenkins and Mr. V. Trenwith for technical, and Mr. A. J. King and Mr. A. Gallup for photographic assistance. The nodules were obtained through the kindness of Dr. W. S. Tegner 
and Dr. J. W. T. Patterson. The Yarrow Research Fund of the London Hospital made a grant towards expenses.

\section{REFERENCES}

Collins, D. H. (1937). J. Path. Bact., 45, 97.

(1939). Annals of the Rheumatic Diseases, 1, 38.

(1949). "The Pathology of Articular and Spinal Diseases". Arnold, London.

Consden, R., Glynn, L. E., and Stanier, W. M. (1952). Biochem. J., 50, xix.

Fawns, H. T., and Landells, J. W. (1953). Annals of the Rheumatic Diseases, 12, 105.

Glynn, L. E., and Loewi, G. (1952). J. Path. Bact., 64, 329.

Hotchkiss, R. D. (1948). Arch. Biochem., 16, 131.

Kellgren, J. H., Ball, J., Astbury, W. T., Reed, R., and Beighton, E. (1951). Nature (Lond.), 168, 493.

Nageotte, J., and Guyon, L.'(1931). Arch., Biol. (Paris), 41, 1.
Pearse, A. G. E. (1953). "Histochemistry". Churchill, London.

Peters, A. (1953). Nature (Lond.), 171, 613.

\section{Etude biochimique des affections rhumatismales}

\section{Le nodule de l'arthrite rhumatismale}

\section{RÉSUMÉ}

(1) La partie centrale molle du nodule rhumatismal consiste de deux éléments:

(a) des fibres collagènes qui ont subi des altérations commençant par l'argyrophilie et aboutissant à leur destruction;

(b) une substance granulaire (fibrineuse) prenant toujours fortement le acide-périodique-Schiff et capable de prendre d'autres colorants de la fibrine.

(2) Ces deux composants peuvent être séparés par l'intervention d'un enzyme: le collagène s'enlève par la collagénase et la substance granulaire par la trypsine. Cette substance granulaire se présente sous deux formes: de grands granules, résistants à la pepsine et de petits, digérés par elle. Les plus grands granules sont acide- phosphotungstique hematoxyline-positifs et se présenten probablement les premiers.

(3) Des altérations secondaires au cours de l'évolutiof̂p? du nodule expliquent les variations de sa compositio et par conséquent de ses réactions de coloration.

(4) Un processus cellulaire actif de synthèse autant que de dégénérescence et de nécrose est nécessaire la formation du nodule.

Estudio bioquímico de las afecciones reumáticas II. El nódulo de la artritis reumatoide

Sumario

(1) La parte central blanda del nódulo reumátic $\vec{\odot}$ consiste de dos elementos:

(a) fibras colagenas que han sufrido alteracione $\vec{\omega}$ comenzando con argirofilia y acabando en sub destrucción;

(b) una substancia granular (fibrinosa) siempre fuerte mente acido-periodico-Schiff-positiva y capaz deu otras reacciones de coloración, como la fibrina.

(2) Estos dos componentes pueden separarse por 19 acción enzimática: el colageno se elimina por la colagene asa y la substancia granular por la tripsina. Esta substancia granular aparece en dos formas: gránulos mayores que resisten a la pepsina y menores, digerido por ella. Los gránulos mayores son ácido-phosphos tungstico-hematoxilino-positivos y aparecen probable mente primeros.

(3) Alteraciones secundarias en el curso de la evoluciók del nódulo explican las variaciones de su composición y, por consiguiente, sus reacciones de coloración.

(4) Un proceso celular activo de síntesis así com\& él de degeneración y de necrosis es necesario paræ formar el nódulo. 